\title{
A necessidade da citação para garantia do devido processo legal nas execuções fiscais: inconstitucionalidade do art. 174, I do Código Tributário Nacional e do Recurso Especial no 1.120.295/SP
}

\author{
The need for a summons to guarantee due legal process in tax \\ foreclosures: unconstitutionality of art. 174, I of the National Tax \\ Code and Special Appeal No. 1.120.295 / SP
}

Julcira Maria de Mello Vianna Lisboa ${ }^{1}$

Guilherme Paes de Barros Geraldi ${ }^{2}$

\begin{abstract}
RESUMO
O presente artigo visou analisar a constitucionalidade do marco interruptivo da prescrição para o ajuizamento de execuções fiscais, na forma estabelecida pelo art. 174, I do Código Tributário Nacional e pelo Recurso Especial $\mathrm{n}^{\mathrm{o}} 1.120 .295 / \mathrm{SP}$, sob o prisma do princípio do devido processo legal, garantido pelo art. $5^{\circ}$, LIV da Constituição de 1988. Para tanto, mediante pesquisa legislativa e jurisprudencial, foram analisadas as razões que levaram às alterações legislativa e jurisprudencial promovida pelos atos em questão e, mediante pesquisa da doutrina nacional, analisou-se o papel do ato de citação no processo e sua relação com o direito de defesa. A primeira análise levou à conclusão de que o objetivo das alterações legislativas foi proteger o crédito tributário e a segunda análise levou à conclusão de que a citação é um elemento essencial ao direito de defesa. Confrontando-se essas duas conclusões preliminares mediante exercício de ponderação, chegou-se à conclusão final de que apesar de adequado à proteção do crédito tributário, a supressão promovida pela Lei Complementar $\mathrm{n}^{\circ} 118$ e pelo Recurso Especial $n^{\circ} 1.120 .295 / \mathrm{SP}$ da relevância do ato de citação para fins de interrupção da prescrição tributária viola o devido processo legal de forma desnecessária, sendo, portanto, inconstitucional.
\end{abstract}

\section{PALAVRAS-CHAVE:}

Prescrição. Execução Fiscal. Inconstitucionalidade

\section{ABSTRACT}

\footnotetext{
1 Professora do Curso de Graduação em Direito e do Curso de Pós-Graduação Stricto Sensu em Direito Constitucional e Processual Tributário da Pontifícia Universidade Católica de São Paulo. Mestre e Doutora em Direito Tributário pela Pontifícia Universidade Católica de São Paulo (PUC-SP).

${ }^{2}$ Mestre em Direito Constitucional de Processual Tributário pela Pontifícia Universidade Catópica de São Paulo (PUC-SP). Adgovado em São Paulo.
} 
This paper aimed to analyze the constitutionality of the limitation period for the filing of tax execution procedures, in the form established by art. 174, I of the National Tax Code and Special Appeal No. 1.120.295 / SP, in terms of due process of law, guaranteed by art. 5, LIV of the 1988 Federal Constitution. For this purpose, the reasons that led to the legislative and case law changes promoted by the acts in question were analyzed and, through research of national doctrine, the role of the personal summons of the defendant in the lawsuit was analyzed and its relationship to the right of defense. The first analysis led to the conclusion that the objective of the legislative changes was to protect the tax credit and the second analysis led to the conclusion that the personal summons of the defendant is an essential element of the right of defense. Facing these two preliminary conclusions, the final conclusion was reached that, although adequate for the protection of tax credit, the suppression promoted by Complementary Law No. 118 and Special Appeal No. 1,120.295 / SP of the relevance of the act summons for the purpose of interrupting the tax prescription violates the due legal process unnecessarily and is therefore unconstitutional.

\section{KEYWORDS:}

Limitation period. Tax Excecution. Unconstitutionality.

\section{INTRODUÇÃO}

Sob o pretexto de proteger o crédito tributário, a legislação tributária vem, ao longo do tempo, sofrendo alterações em relação ao marco interruptivo da prescrição nas execuções fiscais. Essas alterações buscam, primordialmente, desvincular a interrupção da prescrição do ato de citação, diminuindo, paulatinamente, a importância desse ato. No entanto, o fato é que essas alterações são inconstitucionais, na medida em que desrespeitam o princípio do devido processo legal.

A despeito de, por muito tempo, ter sido relegado a um papel secundário, um verdadeiro apêndice do Direito, processo é peça fundamental para a garantia de uma sociedade justa e para a manutenção do estado de direito. O processo é o mecanismo criado pelo direito para garantir sua própria efetividade. Toda vez que alguém entender que um direito seu ou de outro está sendo violado, é por meio do processo que poderá provocar o estado para que este que exerça jurisdição e tutele a situação. Sendo assim, de nada adiantaria que a Constituição salvaguardasse todos os direitos fundamentais nela previstos, se não garantisse, igualmente, que o processo 
para a tutela desses direitos fosse efetivo, célere e justo (CINTRA; GRINOVER; DINAMARCO, 2007, p.46).

É justamente para conferir essas garantias ao processo que a Constituição Federal de 1988 previu em seu art. $5^{\circ}$, LIV o direito ao devido processo legal. Um processo que demore demais, que permita o tratamento desigual entre as partes, que não seja conduzido por um juiz imparcial ou que não garanta ao acusado o pleno direito de defesa, não pode ser considerado como um é um processo que está preocupado com os direitos fundamentais do homem, que a sociedade civilizada tanto batalhou para conquistar. Essa construção mostra que a eficácia material dos direitos fundamentais previstos na Constituição Federal de 1988 depende de sua eficácia processual (BUENO, 2010, 88-91).

Pois bem, em seu texto original, o Código Tributário Nacional (CTN) previa que a prescrição para a ação de cobrança do crédito tributário se interrompia com a citação pessoal do devedor. A Lei Complementar nº 118/2005, modificou essa situação e o CTN passou a prever que o termo interruptivo da prescrição não seria mais a citação do devedor, mas o despacho do juízo que a determinasse. Depois disso, por meio do Recurso Especial (REsp) $\mathrm{n}^{\mathrm{o}}$ 1.120.295/SP, julgado como repetitivo, o Superior Tribunal de Justiça alterou novamente esse marco, que passou a ser o ajuizamento da ação. Desde então, de forma majoritária, a jurisprudência tem considerado que basta que a Fazenda ajuíze a execução fiscal no prazo de 5 anos, que, independentemente da citação do réu, seu crédito está a salvo da prescrição.

Todavia, ao tornar irrelevante a efetiva citação do executado para fins de interromper a prescrição, a legislação e a jurisprudência acabaram por tornar os créditos tributários praticamente imprescritíveis, na medida em se a execução for ajuizada no prazo correto, a citação do devedor pode ser realizada 10, 20 ou 50 anos depois e ainda assim continuará válida. A validade desta situação, no entanto cria enormes problemas ao executado, já que sua defesa dependerá da produção de prova acerca dos eventos ocorridos muito tempo atrás, o que, muitas vezes, será impossível.

Esta situação prejudicial ao exercício de defesa do executado, criada pelas alterações legislativa e jurisprudencial promovidas pela Lei Complementar $n^{\circ} 118 / 2005$ e pelo Recurso Especial $n^{\circ} 1.120 .295 /$ SP é o problema que este artigo se propõe a analisar. O objetivo deste artigo, portanto, é analisar se a supressão da citação pessoal do devedor para fins de interrupção 
do transcurso do prazo prescricional tributário é ou não juridicamente válida. A análise em questão se justifica tanto do ponto de vista teórico como do ponto de vista pragmático, na medida em que o direito ao devido processo legal - possivelmente violado pela supressão da necessidade de citação do executado - é elemento fundamental para a manutenção do estado de democrático de direito, especialmente, no que tange à proteção do cidadão frente à força do Estado. Além disso, as execuções fiscais representam 39\% do acervo de processos pendentes de solução nos órgãos judiciários brasileiros (BRASIL, 2019, p. 131), o que mostra a relevância numérica do problema enfrentado.

A metodologia utilizada para realizar a análise em questão em pesquisa legislativa, doutrinária e jurisprudencial sobre o assunto. De início, será realizada pesquisa legislativa e jurisprudencial, a fim de se compreender as razões que levaram às alterações legislativa e jurisprudencial acerca do termo interruptivo da prescrição tributária.

Depois disso, mediante pesquisa da doutrina nacional, será analisado o papel do ato de citação no processo e sua relação com o direito de defesa.

Espera-se que confrontando-se essas as duas análises mediante exercício de ponderação, seja possível concluir pela juridicidade ou não da supressão promovida pela Lei Complementar $n^{\circ} 118$ e pelo Recurso Especial $n^{\circ} 1.120 .295 / S P$ da relevância do ato de citação para fins de interrupção da prescrição tributária

\section{O PRINCÍPIO DO DEVIDO PROCESSO LEGAL}

\subsection{Origens e Evolução}

No período medieval, a atividade de resolução de conflitos por meio da aplicação do direito era absolutamente arbitrária, especialmente, nos casos em que o estado era parte do conflito. Da mesma forma que o direito não regulava as atividades materiais do estado, que era infalível e irresponsável (the king can do no wrong), o direito também não preestabelecia 
normas procedimentais para o processo de aplicação do direito (MACHADO SEGUNDO, 2004, p. 33).

Nesse período, não havia normas regulando o direito de defesa. Esse direito, na realidade, era tido por absolutamente desnecessário. Afinal, a diligência e discernimento seriam qualidades inerentes aos julgadores. Duvidar dessas qualidades do julgador - que, na grande maioria das vezes, era alguém indicado pelo monarca, quando não ele próprio - seria uma terrível heresia. Com efeito, a sociedade evoluiu. O Estado passou a ser responsável por seus atos e uma consequência natural disso foi a preocupação com o direito de defesa (se o Estado pode errar, é imperioso que o cidadão tenha direito de se defender). E para que esse direito de defesa fosse efetivo, foi necessário o desenvolvimento de institutos de direito processual, dentre os quais, a ideia do devido processo legal (MACHADO SEGUNDO, 2004, p. 33).

A origem histórica do princípio do devido processo legal comumente apontada pela doutrina é a Carta Magna da Inglaterra, de 1215, que em seu artigo/cláusula 39 previa o seguinte (GRINOVER, 1975, p.8-11):

“39 - Nenhum homem livre será detido ou aprisionado, ou privado de seus direitos ou bens, ou declarado fora da lei, ou exilado, ou despojado, de algum modo, de sua condição; nem procederemos com força contra ele, ou mandaremos outros fazê-lo, a não ser mediante o legítimo julgamento de seus iguais e de acordo com a lei da terra."

A expressão "due process of law" não surge, portanto, na Magna Carta. Esse termo surgiu mais de 100 anos mais tarde no Estatuto das Liberdades de Londres (Statute of Westminster of the Liberties of London), também chamado de Lei Inglesa de 1354: "That no Man of what Estate or Condition that he be, shall be put out of Land or Tenement, nor taken, nor imprisoned, nor disinherited, nor put to Death, without being brought in Answer by due Process of the Law" (GRINOVER, 1975, p.8-11).

Séculos depois, a cláusula do due process of law acabou levada para as colônias inglesas na América do Norte junto com o movimento migratório da Europa para a América e incorporado ao direito das colônias. Antes mesmo da elaboração da constituição federal norte americana, vários estados/ex-colônias já previam em suas normas internas o devido processo legal, como é o caso de Maryland, Pensilvânia, Massachusetts, Virgínia e Delaware. 
Posteriormente, o postulado acabou incorporado à Constituição Federal Norte Americana pelas Emendas $5^{\mathrm{a}}(1791)^{3}$ e $14^{\mathrm{a}}(1868)^{4}($ NERY, 2016, p. 107-108).

Em sua origem, no direito inglês, a cláusula do devido processo legal continha caráter instrumental, isto é, não visava um questionamento da substância ou do conteúdo dos atos do Poder Público. Significava simplesmente o direito a um processo regular e justo (NERY, 2016, p. 110).

$\mathrm{O}$ due process of law adentrou as colônias inglesas na América do Norte e ganhou significado diferente a adicional, em especial a partir da $14^{a}$ Emenda à Constituição Norte Americana. Esse novo significado do direito ao devido processo legal era mais voltado à substância das normas do que unicamente uma garantia da ordem processual. É o chamado substantive due process, que atribuiu ao Judiciário norte americano o direito de revisar os atos do parlamento quanto à sua razoabilidade e justiça. Com esse sentido substantivo do devido processo legal, o Judiciário passa a ser o intérprete do sentido da Constituição (NERY, 2016, p. 111-112).

Vale dizer que enquanto na Inglaterra o devido processo legal tinha como escopo a proteção ao direito de defesa, nos Estados Unidos, o devido processo legal passou a ser compreendido como um direito destinado a proteger o cidadão contra todo e qualquer ato do poder público que viesse a restringir sua vida, sua liberdade e sua propriedade. Ou seja, a tríade vida-liberdade-propriedade não poderia sofrer nenhuma restrição, a não ser mediante o devido processo legal (NERY, 2016 p. 110-112).

\footnotetext{
${ }^{3}$ Amendment V (1791)

No person shall be held to answer for a capital, or otherwise infamous crime, unless on a presentment or indictment of a Grand Jury, except in cases arising in the land or naval forces, or in the Militia, when in actual service in time of War or public danger; nor shall any person be subject for the same offence to be twice put in jeopardy of life or limb; nor shall be compelled in any criminal case to be a witness against himself, nor be deprived of life, liberty, or property, without due process of law; nor shall private property be taken for public use, without just compensation.

${ }^{4}$ Amendment XIV (1868)

Section 1. All persons born or naturalized in the United States and subject to the jurisdiction thereof, are citizens of the United States and of the State wherein they reside. No State shall make or enforce any law which shall abridge the privileges or immunities of citizens of the United States; nor shall any State deprive any person of life, liberty, or property, without due process of law; nor deny to any person within its jurisdiction the equal protection of the laws.
} 


\subsection{O conteúdo do direito ao devido processo legal no Brasil}

O direito ao devido processo legal tem previsão constitucional expressa no art. $5^{\circ}$, inciso LIV: "ninguém será privado da liberdade ou de seus bens sem o devido processo legal". Ante a falta de definição legal do alcance desse direito - se processual ou se substancial/material coube à doutrina interpretar o sentido da norma constitucional.

Com efeito, no Brasil, e na maioria dos países de tradição continental, o sentido processual do devido processo legal é o mais difundido e mais aceito. Humberto Ávila (2008, p. 58-59), por exemplo, considera que a face material, ou substancial do devido processo legal não existe no ordenamento jurídico brasileiro, eis que não seria nada além dos deveres de proporcionalidade e razoabilidade, que têm fundamento normativo nos princípios da liberdade e da igualdade. Isto é, para o autor, a proteção à tríade vida-propriedade-liberdade não seria o direito ao devido processo legal, mas os próprios princípios da liberdade e da igualdade.

Sem adentrar em maiores indagações sobre o assunto, até mesmo porque fugiriam do escopo do presente trabalho, entendemos que assiste razão ao autor. No ordenamento jurídico brasileiro, existem disposições normativas específicas para proteger os direitos à vida, à liberdade e à propriedade. Desse modo, seria redundante considerar o direito ao devido processo legal como um direito destinado a proteger essa tríade. Naturalmente, por via reflexa, o direito ao devido processo legal acabará protegendo os direitos à vida, à liberdade e à propriedade, afinal, como dispõe o texto constitucional, "ninguém será privado da liberdade ou de seus bens sem o devido processo legal". Contudo, considerando a existência das já mencionadas disposições normativas específicas à proteção dos direitos à vida, à liberdade e à propriedade, parece-nos que o mais correto é que o direito ao devido processo legal tem um destinatário certo: o processo. Portanto, entendemos que, no ordenamento jurídico brasileiro, o direito ao devido processo legal, tal qual disposto no texto constitucional, diz respeito à sua faceta processual e não substancial.

Vale destacar que esse entendimento não diminui a importância do direito ao devido processo legal. Ao se afirmar que o ordenamento jurídico brasileiro prestigia o devido processo legal processual e não o devido processo legal material não se está diminuindo a importância desse direito, pois não se está afirmando que o devido processo legal é algo destinado a regular meros procedimentos. Nesse sentido, Cassio Scarpinella Bueno (2010, p. 138), explica que o 
princípio do devido processo legal procedimental não deve ser entendido como atinente à procedimentalização do processo, o que só faria sentido se o direito fosse tomado nos termos mais puramente positivistas, ou seja, de modo avalorativo. O princípio em questão “diz respeito à forma de atingimento dos fins do próprio estado" e sustenta que "é pelo devido processo [...] que o Estado Democrático de Direito terá condições de realizar amplamente suas finalidades".

Pois bem, definidas as premissas de que a Constituição Federal de 1988 está se referindo à faceta processual e não à material do princípio ao devido processo legal e a de que isso não diminui a importância desse direito, já que é justamente esta faceta que irá garantir a aplicação dos direitos fundamentais ao processo, falta definir com mais precisão o que é o direito ao devido processo legal processual. Para tanto, busquemos auxílio na doutrina.

Ao estudar os princípios do processo na Constituição Federal de 1988, Nelson Nery Junior (2016, p. 114), esclarece que o "procedural due process of law nada mais é do que a possibilidade efetiva de a parte ter acesso à justiça, deduzindo sua pretensão e defendendo-se do modo mais amplo possível, isto é, de ter his day in Court, na denominação genérica da Suprema Corte dos Estados Unidos”. Continua o autor, explicando que, mais do que a obediência ao procedimento prescrito em lei, o princípio do devido processo legal pressupõe a incidência de isonomia, do contraditório, do direito à prova, da igualdade de armas, da motivação das decisões (administrativas e judiciais), do direito ao silêncio, do direito de não produzir prova contra si mesmo e de não se autoincriminar, do direito de estar presente a todos os atos do processo e fisicamente nas audiências, do direito de comunicar-se em sua própria língua nos atos do processo, da presunção de inocência, do direito ao duplo grau de jurisdição, do direito à publicidade dos atos processuais, direito à razoável duração do processo.

De forma bastante semelhante, Cassio Scarpinella Bueno (2010, p. 137) afirma que este princípio é considerado por boa parte da doutrina como um “ 'princípio-síntese' ou 'princípio de encerramento' de todos os valores que se entende como um processo justo e adequado", que engloba todos os demais princípios processuais previstos pela Constituição. Tem-se, assim, uma via de mão dupla, já que, devido à sua grande abstração, os demais princípios do direito processual, necessariamente, participarão do conceito de devido processo legal, permitindo ao intérprete afirmar o que é e o que não é devido processo legal. 
Ainda conforme Cassio Scarpinella Bueno (2010, p. 137), o princípio do devido processo legal tem o escopo de prescrever as condições mínimas em que o desenvolvimento do processo deve ocorrer, indicando ao Estado-juiz como deve exercer o dever de jurisdição conforme os valores constitucionais. Em outras, palavras, o devido processo legal determina que o Estado-juiz atue em conformidade com o que a Constituição e com as expectativas daqueles que se dirigem ao Judiciário para obter a solução de um conflito. Dessa forma, o princípio em questão confere aos interessados nestas soluções o exercício de todas as possibilidades de ataque e de defesa, concluindo o autor que:

\footnotetext{
“[o] princípio do processo legal, neste contexto, deve ser entendido como o princípio regente da atuação do Estado-juiz desde o momento em que ele é provocado até o instante em que o Estado-juiz, reconhecendo o direito lesionado ou ameaçado, crie condições concretas de sua reparação ou imunização correspondente." (BUENO, 2010, p. 137)
}

Pois bem, os trechos doutrinários expostos acima permitem verificar que o devido processo legal é uma norma bastante abstrata, que exige uma série de condutas por parte do Estado-juiz, tais como o de dispensar tratamento isonômico entre as partes, garantir o direito ao contraditório e à ampla defesa, dar celeridade ao andamento do processo, dentre outras medidas tendente a tornar o processo o mais justo e efetivo possível. De todo modo, essa remissão a outros direitos para definir o que é o direito ao devido processo legal também mostra que esse é um direito cuja definição é muito difícil e que nos leva a pensar o porquê dessa dificuldade.

O início da resposta para esse questionamento parte do fato de que o direito ao devido processo legal é um princípio e não uma regra. A este respeito, destacamos que, no Brasil, existem duas principais correntes a respeito da teoria geral dos princípios.

A primeira dessas duas correntes da teoria geral dos princípios, chamada de escola tradicional do direito público, encabeçada por autores como Celso Antônio Bandeira de Mello (2008, p. 53) e Roque Antonio Carrazza (2014, p. 49), definem os princípios como normas com alto grau de abstração e generalidade e, por isso, exigem uma aplicação influenciada por elevado grau de subjetividade, em contraponto às regras, que tenderiam à concretude e à individualidade. É desta corrente que advém a ideia de os princípios são os alicerces, as vigas mestras ou os valores do ordenamento jurídico.

A segunda corrente considera que as diferenças entre os princípios e as regras não estariam em seu alto conteúdo valorativo ou grau de abstração, mas na sua estrutura e forma de 
aplicação. Essa corrente explica que as regras têm estrutura normativa fechada e estabelecem deveres definitivos. Por conta disso, as regras são aplicadas por subsunção, não admitindo diferentes graus de aplicação (ou a norma se aplica ou não se aplica). Já os princípios, tem estrutura normativa aberta, estabelecendo mandamentos de otimização. Ou seja, o consequente das normas do tipo princípio não contém um mandamento fechado, mas uma determinação de que, na medida do possível - isto é, conforme as circunstâncias fáticas e jurídicas permitam a conduta deverá ser tomada no sentido que a norma indica. Por isso, os princípios não são aplicados por subsunção, mas mediante ponderação (ÁVILA, 2012, p. 314-317).

Não pretendemos, no presente trabalho, aprofundar a análise das diferenças entre as duas correntes doutrinárias, nem avaliar qual delas é dotada do maior rigor científico. O que pretendemos demonstrar com essa breve explanação é que adotando as premissas de uma ou de outra corrente, o resultado será o mesmo para o presente caso: o direito ao devido processo legal será considerado sempre um princípio.

O direito ao devido processo legal é um princípio porque é uma norma de alta carga valorativa e abstração, que funciona como uma viga mestra que orienta a interpretação e a aplicação de todas as normas que regulam o direito processual. E é um princípio porque funciona como um comando de otimização, que indica um "estado ideal de coisas", a ser promovido, sem, contudo, indicar condutas concretas que devem ser tomadas para alcançá-los.

A não indicação dessas condutas necessárias para se atingir o "estado ideal" que a norma do tipo princípio almeja não é uma falha, mas algo proposital. Devido ao alto grau de abstração do conteúdo desse "estado ideal de coisas", a prescrição a priori dessas condutas seria impossível ou diminuiria o conteúdo da norma, tornando-a menos eficaz quando não ineficaz. Devido a essa dificuldade, os princípios não prescrevem a priori as condutas que devem ser realizadas quando determinado fato jurídico previsto na hipótese normativa acontecer no mundo fenomênico. Eles apenas prescrevem o mandamento de otimização, que deve ser aplicado a posteriori, mediante análise das circunstâncias jurídicas e fáticas do caso concreto.

Como explica Humberto Ávila (2008, p. 54-55) o dever de realização dos princípios implica a tomada de condutas adequadas, necessárias e proporcionais ao atingimento desse estado ideal. Esclarecendo essa ideia, é possível afirmar que havendo o dever de realizar um princípio, há o dever de se tomar condutas que sejam adequadas para se alcançar o "estado 
ideal de coisas" almejado pelo princípio em questão, bem como o de não se tomar condutas inadequadas para tanto. Todavia, o ordenamento jurídico brasileiro não prescreve apenas um princípio, mas vários. Dessa forma, a tomada de condutas adequadas para se alcançar um princípio pode, a rigor, ser inadequada à realização de outro princípio, o que não é desejável. Por isso, as condutas não precisam ser apenas adequadas, mas devem ser necessárias para a realização daquele princípio. Dito de outro modo, dentre todos os comportamentos adequados para proteger um princípio, deve ser escolhido aquele que restringe em menor medida o outro princípio, que precisa ser igualmente promovido. A escolha de qualquer outro comportamento, que não aquele que restringe em menor medida o outro princípio, será uma escolha errada, já que estará restringindo o outro princípio sem necessidade. $\mathrm{O}$ aprofundamento dessa ideia de necessidade leva á ideia de proporcionalidade, na medida em que, na prática, a tomada de medidas adequadas à consecução de um princípio não afetará somente um outro princípio, mas vários. Desse modo, a escolha de uma medida adequada à realização de um princípio deve preservar, no maior grau possível, os demais princípios.

A nosso ver, é aí que reside a grande dificuldade de definir o conteúdo do princípio do devido processo legal. Ele é dotado de alta carga valorativa e abstração, ao mesmo tempo em que sua estrutura normativa não prescreve um comando concreto, mas apenas um mandamento de otimização. Quão devido deve ser o processo? Que condutas devem ser tomadas para que o processo seja considerado devido o suficiente? O direito positivo não dá essas respostas e, nem deveria dar, sob pena de restringir o alcance do devido processo legal. É somente analisando cada caso concreto que se pode concluir se o processo é ou não é devido. Ou melhor, se um processo determinado observou ou não o princípio do devido processo legal.

Diante de tudo o que foi exposto, torna-se possível afirmar que a Constituição Federal de 1988 prescreve, em seu art. $6^{\circ}$, LIV, o direito ao devido processo legal em sua faceta processual, que exige que o processo seja o mais justo e adequado possível para a tutela do direito cuja tutela jurisdicional é requerida. O conteúdo desse direito é propositalmente genérico e abstrato, já que ele é prescrito por uma norma do tipo princípio e não por uma regra. Sendo assim, é somente a análise do caso concreto que permitirá ao intérprete averiguar se o princípio do devido processo legal foi ou não respeitado. 
Fixadas essas premissas, no próximo capítulo, vamos analisar se as alterações promovidas pela Lei Complementar $n^{\circ} 118 / 2005$ e, posteriormente, pelo Recurso Especial $\mathrm{n}^{\mathrm{o}} 1.120 .295 / \mathrm{SP}$ ofendem de alguma maneira o princípio do devido processo legal.

\section{A PRESCRIÇÃO TRIBUTÁRIA E AS EXECUÇÕES FISCAIS}

\subsection{Noções gerais}

A obrigação tributária nasce com a ocorrência do fato imponível e, a partir deste momento, o sujeito passivo fica vinculado ao sujeito ativo, ficando seu patrimônio onerado até que se liberte do estado de sujeição. Por força do princípio da legalidade, da mesma forma que é a lei quem estabelece os critérios para o nascimento da obrigação tributária, será a lei quem estabelecerá os critérios para sua extinção, ou seja, para a liberação da oneração do patrimônio do sujeito passivo, do liame obrigacional.

Com efeito, como obrigação que é, a obrigação tributária nasce para ser extinta. A forma de extinção das obrigações, por excelência é o pagamento, que representa seu cumprimento. Todavia, a fim de impedir a perpetuação das obrigações, conferindo segurança jurídica e certeza do direito ao sistema jurídico, o próprio sistema prevê outras causas, "anormais" para sua extinção. Assim, se verificando o aparecimento de qualquer uma delas, o liame obrigacional, que vinculava o sujeito passivo ao sujeito ativo e onerava seu patrimônio desaparece.

$\mathrm{O}$ art. 156 do Código Tributário Nacional $(\mathrm{CTN})^{5}$ traz o rol das causas extintivas da obrigação tributária, elencando, dentre essas causas, a prescrição e a decadência. Devido ao escopo deste trabalho, analisaremos somente a prescrição.

Com efeito, Roque Antonio Carrazza (2010, p. 348) define a prescrição como "a perda da ação inerente ao direito e de toda sua capacidade defensiva, por seu não-exercício, por um

\footnotetext{
5 “Art. 156. Extinguem o crédito tributário:

$[\ldots]$

V - a prescrição e a decadência;

$[\ldots] "$.
} 
certo lapso de tempo" e, ainda, como "o decurso do tempus, fixado no direito positivo, que determina a ocorrência deste fenômeno jurídico". No entender do autor, são quatro os requisitos necessários à configuração da prescrição: (i) a existência de uma ação exercitável; (ii) a inércia de seu titular; (iii) o prolongamento desta inércia durante certo lapso temporal; e (iv) a ausência de qualquer ato ou fato que tenha o condão de impedir, interromper ou suspender a fluência deste lapso temporal. Nota-se, assim, que além do transcurso do lapso temporal determinado na lei, é necessário que também haja a desídia do titular do direito para a prática do ato estabelecido pela lei como capaz de interromper a fluência desse prazo. É justamente a compreensão acerca desse ato que é a grande causadora de divergências entre o fisco e os contribuintes no que tange ao prazo prescricional para o ajuizamento de execuções fiscais.

\subsection{O marco interruptivo da prescrição tributária}

Por força do disposto no art. 146 da Constituição Federal, a regulamentação da decadência e da prescrição em matéria tributária - bem como todos os aspectos a ele relacionados, como seus termos iniciais e finais, causas interruptivas e suspensivas, etc. - foram colocadas sob a reserva de lei complementar. ${ }^{6}$ Ao fazer isso, a Constituição Federal de 1988 considerou que a decadência e a prescrição tributárias, seriam normas gerais de direito tributário, ou seja, normas de caráter nacional, que vinculam todos os entes tributantes (CARRAZA, 2014, p. 169).

Com efeito, em sua redação original, o art. 174 do CTN dispunha que a prescrição da ação para a cobrança do crédito tributário era interrompida pela citação pessoal do devedor. Havia, portanto, alinhamento entre o que dispunha o Código de Processo Civil ${ }^{7}$ para a prescrição das ações em geral e o que dispunha o Código Tributário Nacional para a prescrição das execuções fiscais. Esse panorama foi, no entanto, alterado em 2005, pela Lei Complementar

\footnotetext{
${ }^{6}$ Art. 146. Cabe à lei complementar:

[...]

III - estabelecer normas gerais em matéria de legislação tributária, especialmente sobre:

[...]

b) obrigação, lançamento, crédito, prescrição e decadência tributários;

[...]

${ }^{7}$ Art. 219. A citação válida torna prevento o juízo, induz litispendência e faz litigiosa a coisa; e, ainda quando ordenada por juiz incompetente, constitui em mora o devedor e interrompe a prescrição. (Redação dada pela Lei $\underline{\left.\mathrm{n}^{\circ} 5.925, \text { de } 1^{\circ} .10 .1973\right)}$
} 
$n^{o}$ 118. Esse diploma normativo mudou o termo interruptivo da prescrição da citação pessoal do devedor para o despacho que determina a citação.

Vale destacar que a Lei Complementar $\mathrm{n}^{\circ} 118 / 2005$ foi promulgada com o intuito de adequar o CNT à então nova lei de recuperação judicial e falência (Lei n n 11.101/2005), que tramitava no Legislativo Federal. Para atender esse fim de dar tratamento uniforme à matéria nos dois diplomas, era necessário alterar os dispositivos do Código Tributário Nacional que dispunham sobre as garantias e privilégios do crédito tributário (arts. 183 a 193). O projeto de lei original ${ }^{8}$ previa alterações apenas em relação a esses dispositivos. No entanto, a Comissão de Assuntos Econômicos do Senado Federal apresentou substitutivo integral ${ }^{9}$, que promoveu a alteração em comento do art. 174, I do CTN, que passou a prever que o despacho que ordena a citação - e não mais a citação pessoal do devedor - interrompe a prescrição da ação para a cobrança do crédito tributário.

A justificativa apresentada pela comissão para a alteração foi a de que era necessário promover alterações no Projeto da Câmara para adequá-lo ao projeto substitutivo da nova lei de recuperação judicial e falência que o Sanado havia devolvido à Câmara. Vale notar, todavia, que não localizamos nenhum dispositivo da referida lei que verse sobre a prescrição do crédito tributário. Para nós, a impressão que fica é a de que o verdadeiro intuído da alteração do art. 174, I do CTN foi a de proteger o crédito tributário. Com a retirada da necessidade de citar o executado para interromper o curso da prescrição tributária, estar-se-ia facilitando o exercício de direito de ação do fisco e, reflexamente, preservando o crédito tributário. O objetivo seria nobre, afinal, preservando os tributos contra os maus pagadores, estar-se-ia preservando o interesse público, já que o destino dos tributos é custear as despesas públicas.

No entanto, o custo para se atender a este interesse tão nobre, era bastante alto e envolvia o enfraquecimento do direito de defesa do contribuinte/executado. Esse custo foi percebido pela Câmara dos Deputados e gerou debate. ${ }^{10}$ Nesse sentido, a Comissão de Finanças e Tributação

\footnotetext{
${ }^{8}$ O Projeto de Lei Complementar o ${ }^{\circ}$ 70/2003, da Câmara dos Deputados. Os arquivos da tramitação podem ser visualizados em: 〈https://www.camara.leg.br/proposicoesWeb/fichadetramitacao?idProposicao=125572>, consultado em 22.06.2019.

$9 \quad$ https://legis.senado.leg.br/sdleg-getter/documento?dm=4484629\&ts=1559275424952\&disposition=inline >, consultado em 22.06.2019.

10 A íntegra do debate pode ser consultada na Questão de Ordem no 481/04: $<$ https://www.camara.leg.br/proposicoesWeb/prop mostrarintegra;jsessionid=48FD8D8A942E2A575D2205DA $\underline{\text { 8A7F2ACC.proposicoesWebExterno2? codteor }=260083 \& \text { filename }=\text { Tramitacao-PLP }+72 / 2003>}>$, consultado em 22.06.2019.
} 
da Câmara, apresentou parecer rejeitando a alteração promovida pelo Senado em relação ao art. 174, I do CTN, sob a seguinte justificativa:

\begin{abstract}
"Há que se ressaltar que a maioria das alterações propostas mostra-se adequada e aperfeiçoa os procedimentos falimentares em face dos créditos tributários. No entanto, devemos citar alguns aspectos que criarão situações de enorme prejuízo para a sociedade. Primeiramente, quanto à alteração proposta ao art. 174 do Código, devemos ressaltar que, caso seja aprovado o substitutivo do Senado, simplesmente não existirá mais prescrição para as ações de cobrança de crédito tributário, haja vista que a interrupção da prescrição dar-se-á pelo despacho do juiz que ordenar a citação e a execução fiscal. Entendemos que, se adotada, tal medida simplesmente revogará o direito de prescrição do devedor, pelo que apresentamos a emenda em anexo." (BRASIL, 2004)
\end{abstract}

Apesar disso, as emendas para a supressão da alteração proposta pelo Senado em relação ao art. 174, I não foram aprovadas, por motivos inerentes ao processo legislativo. Desse modo, a Lei Complementar no 118/2005 foi aprovada e entrou em vigor em 9 de maio de 2005, alterando, desta data em diante, o marco interruptivo da prescrição do crédito tributário para a data do proferimento do despacho do juiz que determina a citação do executado na execução fiscal.

Até mesmo pelo recorte temático selecionado para este trabalho, não analisaremos a correção ou não da não aprovação das emendas supressivas apresentadas pela Câmara em relação ao substitutivo apresentado pelo Senado ao projeto de lei que culminou na alteração do art. 174, I do CTN. No entanto, parece-nos que, em seu mérito jurídico, as emendas supressivas apresentadas pela Câmara dos deputados estavam corretas, já que, de fato, a alteração do marco interruptivo da prescrição da ação para a cobrança do crédito tributário para o despacho citatório tem o condão de, na prática, tornar imprescritível o crédito tributário.

De todo modo, em 2010, o STJ julgou, como representativo de controvérsia, o Recurso Especial (REsp) no 1.120.295/SP e decidiu que, a despeito da previsão legal, o crédito tributário estaria a salvo da prescrição se a execução fiscal fosse ajuizada antes do decurso do prazo de 5 anos. Desde então, de forma majoritária, a jurisprudência tem considerado que basta que a Fazenda ajuíze a execução fiscal no prazo de 5 anos, que, independentemente do despacho citatório e da citação do réu, seu crédito está a salvo.

É certo que tanto a alteração legal, promovida pela lei Complementar $\mathrm{n}^{\circ} 118$, como a alteração da orientação jurisprudencial tiveram como escopo a nobre tarefa de proteger o crédito tributário dos maus pagadores, impedindo que estes se utilizassem de subterfúgios para frustrar 
a citação, aguardando a prescrição para se verem livres de suas obrigações tributárias sem o devido pagamento. No entanto, também é certo que a proteção do crédito tributário não pode suplantar o princípio do devido processo legal, que foi a consequência dessas duas alterações no marco interruptivo da prescrição.

\subsection{Prescrição, citação, direito de defesa e o devido processo legal}

No item anterior, afirmamos que a alteração do marco interruptivo da prescrição do direito de ação para a cobrança do crédito tributário da citação pessoal do devedor, primeiramente, para o momento em que é proferido o despacho que determina a citação e, posteriormente, por orientação jurisprudencial, para o momento em que a execução fiscal é ajuizada contrariou o princípio do devido processo legal. Cumpre-nos agora demonstrar as razões de tal afirmação e explicar por que, em nossa concepção, o marco interruptivo originalmente escolhido pelo legislador - a citação pessoal do devedor - atendia aos preceitos do princípio do devido processo legal.

Pois bem, como já exposto, em sua redação original, o art. 174 do Código Tributário Nacional dispunha que a prescrição para o ajuizamento da ação de cobrança do crédito tributário se interrompia com a citação pessoal do devedor. Conforme as lições de Renato Lopes Becho (2018, p. 84) essa escolha foi coerente com a tradição processual brasileira e com a legislação vigente à época.

De fato, quando da promulgação do Código Tributário Nacional, em 1966, vigia o Código de Processo Civil de 1939 (Decreto-lei no 1.0608/39), que, em seu art. 166, dispunha, conforme a redação que lhe foi dada pelo Decreto-lei n ${ }^{\circ} 4.565 / 42$ :

Art. 166. A citação válida produz os seguintes efeitos:

$[\ldots]$

$\mathrm{V}$ - interrompe a prescrição.

[...]

$\S 2^{\circ}$ A prescrição considerar-se-á interrompida na data do despacho que ordenar a citação, ficando inválido, para esse efeito, o despacho, se a citação não for promovida pelo interessado no prazo de dez dias, contados da data do despacho, prazo que poderá ser prorrogado até o máximo de noventa dias, a critério do juiz, por motivo fundamentado. 
Ou seja, desde aquela época, já se considerava que a citação do devedor era o marco interruptivo da prescrição, havendo previsão de retroação desse marco para uma data pretérita - no caso, a data do despacho citatório - caso a citação fosse promovida pelo interessado num determinado lapso de tempo.

Essa situação não foi alterada pelo o Código de Processo Civil de 1973 (Lei $\left.n^{\circ} 5.689 / 73\right)$. Seu artigo 219 previa o seguinte:

Art. 219. A citação válida torna prevento o juízo, induz litispendência e faz litigiosa a coisa; e, ainda quando ordenada por juiz incompetente, constitui em mora o devedor e interrompe a prescrição.

$\S 1$ 1o A interrupção da prescrição retroagirá à data da propositura da ação.

$\S 20$ Incumbe à parte promover a citação do réu nos $10(\mathrm{dez})$ dias subseqüentes ao despacho que a ordenar, não ficando prejudicada pela demora imputável exclusivamente ao serviço judiciário.

§ 3o Não sendo citado o réu, o juiz prorrogará o prazo até o máximo de 90 (noventa) dias.

§ 4o Não se efetuando a citação nos prazos mencionados nos parágrafos antecedentes, haver-se-á por não interrompida a prescrição.

$[\ldots]$

Assim, na mesma forma que o diploma de 1937, o Código de Processo Civil de 1973 previa que o marco interruptivo da prescrição era a citação do devedor, sendo certo que esse marco poderia retroagir a uma data pretérita - agora, a data da propositura da ação - caso a citação fosse promovida pelo interessado num determinado lapso de tempo.

Com efeito, com o advento do Código de Processo Civil de 2015, também não se alterou, em sua substância, essa situação:

\footnotetext{
Art. 240. A citação válida, ainda quando ordenada por juízo incompetente, induz litispendência, torna litigiosa a coisa e constitui em mora o devedor, ressalvado o disposto nos arts. 397 e 398 da Lei no 10.406, de 10 de janeiro de 2002 (Código Civil). $\S 1^{\circ} \mathrm{A}$ interrupção da prescrição, operada pelo despacho que ordena a citação, ainda que proferido por juízo incompetente, retroagirá à data de propositura da ação.

$\S 2^{\circ}$ Incumbe ao autor adotar, no prazo de 10 (dez) dias, as providências necessárias para viabilizar a citação, sob pena de não se aplicar o disposto no $\S 1^{\circ}$.

$\S 3^{\circ}$ A parte não será prejudicada pela demora imputável exclusivamente ao serviço judiciário.

$\S 4^{\circ} \mathrm{O}$ efeito retroativo a que se refere o $\S 1^{\circ}$ aplica-se à decadência e aos demais prazos extintivos previstos em lei.
}

No diploma processual civil atualmente vigente, portanto, o regramento continua, em sua essência, sendo o mesmo: a prescrição retroagirá se, e somente se, o autor promover, dentro do prazo de 10 dias, os atos necessários á citação efetiva do réu. 
Apesar de extensa, a menção aos dispositivos legais que regulamentam a interrupção da prescrição no direito processual positivo é necessária para demonstrar que ainda que sempre tenha havido preocupação em proteger o interesse do autor, reconhecendo-se a relevância do momento em que ele apresenta a petição inicial, provocando o Estado-juiz, para a interrupção da prescrição, este ato nunca foi considerado como suficiente para tanto.

A análise dos dispositivos transcritos acima evidencia que o direito positivo sempre impôs como condição para que o prazo prescricional retroagisse - à data do ajuizamento da ação ou à data do despacho citatório - que o credor promovesse, num determinado prazo, os atos necessários para a efetiva citação do réu. É, e sempre foi, a citação válida que ocasiona a interrupção da prescrição. Essa interrupção pode retroagir, desde que a citação ocorra nos prazos previstos na legislação. Ocorrendo a citação fora desses prazos, por fato imputável à parte, a interrupção pode ainda ocorrer, mas não retroagirá à data da propositura da ação ou do despacho citatório (WAMBIER, 2015, p. 346-347).

Mas qual seria a razão para essa enorme importância dada à citação válida do réu? Se, como visto no Tópico 2.1, a prescrição se caracteriza pela inércia do titular do direito por um determinado período, o ajuizamento da ação já não quebraria essa inércia?

De fato, a apresentação da petição inicial é um ato essencial para a quebra da inércia pelo titular do direito e sua importância é reconhecida pelo direito positivo. Contudo, a apresentação da petição inicial é um ato meramente preparatório, uma preliminar necessária para a prática do ato que, efetivamente, resultará a quebra da inércia por parte do titular da ação: a citação do réu.

Como explica Luiz Rodrigues Wambier (2015, p. 345), a relação jurídica processual começa a ser formada com o ato de propositura da demanda, mediante distribuição ou despacho na petição inicial. Até esse momento, todavia, a relação é formada apenas entre autor e juiz. A despeito de já produzir alguns efeitos, o fato é que esta relação não se encontra completa, ante a ausência do réu, que, até então, não tem ciência da demanda contra si proposta. É somente com a efetiva citação do réu que a relação jurídica processual assume sua configuração angular.

Aprofundando a questão, Cassio Scarpinella Bueno (2009, p. 201), afirma que com a apresentação da petição inicial, o exequente rompe a inércia da jurisdição e pede que lhe seja 
prestada tutela jurisdicional, exercendo seu direito de ação. Distribuída e recebida a inicial, todavia, "a citação do executado é medida indispensável à luz do princípio da ampla defesa".

Tratando especificamente das execuções fiscais, Renato Becho (2018, p. 99) assevera que é somente a citação que trás o terceiro ator para o feito. Somente com a citação, o réu saberá que contra ele há uma demanda e que seu direito e seu patrimônio estão em jogo. Bem assim, é somente com a citação que o executado poderá se apresentar em juízo e deduzir defesa.

Os excertos doutrinários demonstram que a citação é o ato essencial ao direito de defesa do réu. É somente com citação que o réu toma ciência da pretensão existente contra si e pode preparar sua defesa. Com efeito, a demora para a realização da citação pode prejudicar o direito de defesa do réu e, como visto no Capítulo 1 deste artigo, o princípio do devido processo legal tem como finalidade, promover o direito de defesa da forma mais ampla e justa possível.

Uma demonstração clara que a demora para a citação pode causar ao direito de defesa - e, consequentemente, ao devido processo legal - está ligada ao dever de guarda de documentos. O art. 195, Parágrafo único do Código Tributário Nacional determina que os livros contábeis e fiscais, bem como os comprovantes dos lançamentos - ou seja, toda a documentação contábil e físcal - devem ser conservados até a prescrição dos créditos tributários decorrentes das operações a que se refiram. A rigor, portanto, esses documentos deveriam ser guardados pelo prazo de 5 anos. Mas, na prática, esses documentos têm que ser guardados indefinidamente. Afinal, se a citação for considerada um ato desnecessário para a interrupção da prescrição tributária, nada impede que a execução fiscal seja ajuizada dentro do prazo prescricional e o executado seja citado 10, 20 ou 50 anos depois. Nesse momento, esses documentos ainda existirão? Estarão legíveis? O contador que os elaborou estará vivo para sanar eventuais dúvidas acerca da escrita contábil e fiscal?

Vale lembrar que, em se tratando de uma execução fiscal, em que o direito do exequente está pré-constituído pela certidão de dívida ativa, é do executado o ônus de demonstrar que o título em questão não é dotado de certeza, liquidez ou exigibilidade. Para tanto, a escrita contábil e fiscal e essencial.

O tempo é essencial ao exercício do direito de defesa, de modo que uma citação tardia pode por em cheque o direito de defesa do executado. 
Diante do que foi exposto, fica claro que a citação é um ato essencial ao direito de defesa e, portanto, um ato exigido pelo devido processo legal. É em razão disso que a despeito de reconhecer o ajuizamento da ação como um momento importante para a caracterização da quebra da inércia por parte do titular do direito - e, portanto, um marco importante para a interrupção da prescrição - o direito processual nunca permitiu que esse ato, isoladamente, fosse suficiente para tanto. Preocupado em compatibilizar o direito do autor com o direito de defesa do réu, o direito processual, sempre reconheceu que o ato da apresentação da petição inicial é um ato, meramente preliminar, que precisa ser completado pelo despacho citatório, seguido da efetiva citação do réu para caracterizar, por completo, a quebra da inércia e gerar o efeito jurídico de interromper o fluxo da prescrição.

\subsection{Prescrição tributária e devido processo legal: o marco interruptivo deve ser a citação}

No item anterior, foi demonstrado que o direito processual civil sempre elegeu o momento da citação como o marco interruptivo da prescrição, possibilitando a retroação desse marco para o momento do ajuizamento da ação ou do despacho que determina a citação como forma de compatibilizar máxima proteção ao direito de ação do autor e também ao direito de defesa do réu. Em sua redação original, o Código Tributário Nacional respeitou essas diretrizes, mas, devido a sucessivas alterações legislativas e jurisprudenciais, atualmente, o momento da citação passou a ser absolutamente irrelevante para a fixação do marco interruptivo da prescrição da ação para a cobrança de créditos tributários.

O primeiro diploma a fazer isso foi a Lei n 6.830/80 (a Lei de Execução Fiscal), que fixou em seu art. $8^{\circ}, \S 2^{\circ}$ o despacho do juiz que ordena a citação como marco interruptivo da prescrição da execução fiscal. Posteriormente, o Código Tributário Nacional incorporou essa mudança por meio da Lei Complementar $n^{\circ} 118 / 2005$, no contexto apresentado no Item 2.2 deste trabalho, e, da mesma forma que a lei de execução fiscal, passou a prever que a prescrição é interrompida pela prolação do despacho que determina a citação, mantendo-se silente quanto à necessidade da tomada dos atos necessários para a efetivação da citação, como fazia legislação processual civil. 
Diante desse silêncio, o STJ se manifestou no julgamento do Recurso Especial $\mathrm{n}^{\mathrm{o}}$ 1.120.295/SP e considerou que o simples protocolo da petição inicial seria suficiente para caracterizar quebra de inércia por parte da Fisco e que, portanto, este deveria ser o marco interruptivo da prescrição tributária. Na concepção do STJ, portanto, a efetiva citação do executado é um ato absolutamente irrelevante para a interrupção da prescrição. Ajuizada a execução dentro do prazo prescricional, o executado pode levar o tempo que for necessário para ser citado, que, ainda assim, o direito de ação do Fisco estará resguardado.

Entendemos, todavia, que tanto a opção legislativa adotada por meio da Lei Complementar $\mathrm{n}^{\mathrm{o}}$ 118/2005, como a orientação jurisprudencial tomada pelo STJ no julgamento do Recurso Especial n ${ }^{\circ}$ 1.120.295/SP não são juridicamente válidas perante o ordenamento constitucional brasileiro, já que violam o princípio do devido processo legal.

Para demonstrar a correção dessa afirmativa, o primeiro ponto é analisar quais foram as razões para as alterações promovidas no marco interruptivo da prescrição tributária.

Como já exposto, a razão imediata para tanto foi a defesa do direito de ação do Fisco e a razão mediata foi a proteção ao crédito tributário. Isto é, em razão da nobreza do crédito tributário - que tem como finalidade, abastecer os cofres públicos, a fim de que o Estado possa cumprir suas funções institucionais - o direito de ação do Fisco mereceria tratamento diferenciado, bastando que o fisco ajuizasse a ação, ou obtivesse o despacho citatório para que a prescrição fosse interrompida. No entanto, como também já foi exposto (item 2.3), a proteção do interesse fiscal prejudica o direito o direito de defesa do contribuinte, que está inserido no âmbito do princípio do devido processo legal.

Pois bem, como exposto no Capítulo 1, o direito ao devido processo legal é um princípio e não uma regra. Na condição de princípio, ele não prescreve condutas concretas que devam ser adotadas, mas prescreve um estado ideal de coisas - qual seja, que o processo deve ser o mais justo e o mais adequado possível para a tutela do direito - que devem ser buscadas pelo aplicador da lei na maior medida possível, ante as circunstâncias do caso concreto, mediante exercício de ponderação (ÁVILA, 2008, p. 57-58).

Assim, por força do princípio do devido processo legal, toda e qualquer medida tomada no âmbito de um processo deve passar por esse exercício de ponderação, que demanda a análise 
de três questões. A medida tomada é adequada para o atingimento do estado ideal de coisas prescrita pelo princípio? A medida tomada é necessária, isto é, dentre todos os comportamentos adequados para proteger esse estado ideal de coisas, este é aquele que restringe em menor medida o outro princípio, que precisa ser igualmente promovido. A escolha de qualquer outro comportamento, que não aquele que restringe em menor medida o outro princípio, será uma escolha errada, já que estará restringindo o outro princípio sem necessidade. Caso a medida seja adequada e necessária, deve-se analisá-la sob a perspectiva da proporcionalidade, na medida em que, na prática, a tomada de medidas adequadas à consecução de um princípio não afetará somente um outro princípio, mas vários. Desse modo, a escolha de uma medida adequada e necessárioa à realização de um princípio deve preservar, no maior grau possível, os demais princípios.

Iniciemos, portanto, a análise da adequação. Para tanto, devemos perguntar se a fixação do termo interruptivo da prescrição em momentos anterior à citação do executado foi adequada à finalidade de proteger o crédito tributário? Entendemos que a resposta é positiva. De fato, a medida é adequada para atingir o fim pretendido.

No entanto, não se pode esquecer que existem outros direitos envolvidos na questão. Por isso, é preciso chegar ao segundo critério de ponderação: a medida adotada é necessária para o atingimento do fim pretendido, ou há outros meios, menos gravosos para atingir o mesmo fim.? Dessa vez, parece-nos que a resposta e negativa. Não é necessário prejudicar o direito de defesa do executado preservar o crédito tributário e o direito de ação do Fisco da prescrição, haja vista que há uma série de outras medidas que podem ser tomadas sem causar nenhum prejuízo ao direito de defesa do executado, pela demora para a promoção da citação.

A título de exemplo, em primeiro lugar, como aponta Renato Becho (2018, p. 111), as procuradorias poderiam ajuizar as execuções fiscais em datas mais próximas à constituição definitiva do crédito, tendo, assim, mais tempo para promover a citação. Poderiam também, acompanhar as execuções com mais diligência, utilizando-se de sistemas de acompanhamento processual eletrônico interligado com os sistemas dos tribunais, que mostrassem, por exemplo, 
que o aviso de recebimento não retornou no prazo de 15 dias estabelecido por lei $^{11}$, permitindo a solicitação de citação por oficial de justiça ou por edital.

Enfim, há uma série de medidas que poderiam ser tomadas pelos exequentes em execuções fiscais tendentes a buscar a efetiva citação dos executados antes de buscar uma alteração legislativa ou uma interpretação jurisprudencial que prejudique o direito de defesa dos contribuintes (BECHO, 2018, p. 111). Há uma série de medidas menos gravosas ao direito de defesa do executado que a supressão da necessidade de promoção de sua citação para a interrupção da prescrição tributária. Assim, a supressão da necessidade de citação mostra-se como uma medida desnecessária e, portanto, que fere indevidamente o princípio do devido processo legal.

Vê-se, assim, que as alterações do marco interruptivo da prescrição tributária promovidas pela Lei Complementar $n^{\circ} 118 / 2005$ e pelo REsp $n^{\circ} 1.120 .295 / \mathrm{SP}$ violam o princípio do devido processo legal e, por conta disso, são inconstitucionais.

\section{CONCLUSÃO}

Diante de tudo o que foi exposto, verificamos que o processo é o instrumento criado pelo direito para atribuir efetividade a ele mesmo. Toda vez que um direito for ou estiver em risco de ser violado, é por meio do processo que se provocará o Estado-juiz para que este exerça o dever de jurisdição e tutele a situação, reestabelecendo a ordem jurídica.

Verificamos também que o direito ao devido processo legal, representa a eficácia processual dos direitos fundamentais elencados na Constituição Federal de 1988. Afinal, de

\footnotetext{
${ }^{11}$ Lei de Execução Fiscal: “art.8oArt. $8^{\circ}$ - O executado será citado para, no prazo de 5 (cinco) dias, pagar a dívida com os juros e multa de mora e encargos indicados na Certidão de Dívida Ativa, ou garantir a execução, observadas as seguintes normas:

$[\ldots]$

III - se o aviso de recepção não retornar no prazo de 15 (quinze) dias da entrega da carta à agência postal, a citação será feita por Oficial de Justiça ou por edital;"
} 
nada adiantaria que a Constituição Federal salvaguardasse em seu bojo tantos direitos fundamentais e não exigisse que o processo para sua tutela fosse dotado de iguais garantias.

O devido processo legal é um princípio, já que além de ser uma norma de alta carga valorativa e abstração, que atua como a viga mestra do direito processual, sua estrutura é a de um mandamento de otimização. Isto é, o consequente da norma constitucional que garante o direito ao devido processo legal não prescreve condutas concretas. Prescreve apenas um "estado ideal de coisas", que obriga o aplicador do direito a sempre ponderar se, no caso concreto, as medidas que estão sendo tomadas são adequadas, necessárias e proporcionais ao seu atingimento. Caso não o sejam, o princípio estará sendo violado e, portanto, tratando-se de um princípio constitucional, a medida adotada será inconstitucional.

Partindo dessa premissa, analisamos as alterações promovidas pela Lei Complementar $n^{\circ} 118 / 2005$ e pelo Recurso Especial n ${ }^{\circ} 1.120 .295 /$ SP. Sob o pretexto de proteger o crédito tributário, ambos passaram a desconsiderar o ato da citação como um ato relevante para a interrupção da prescrição tributária e estabeleceram como marco interruptivo da prescrição da execução fiscal, num primeiro momento, o mero despacho citatório e, posteriormente, o mero ajuizamento da execução fiscal.

Essa análise levou à conclusão de que a citação é um ato essencial para o direito de defesa, de modo que a demora para a realização da citação prejudica o direito de defesa do executado. Um exemplo claro desse prejuízo é o dever de guarda de documentos contábeis e fiscais, que são essenciais à defesa na execução fiscal, haja vista que é ônus do contribuinte desconstituir a presunção de veracidade da certidão de dívida ativa. Se com o mero ajuizamento, a prescrição está interrompida, como saber por quanto tempo o contribuinte precisa guardar esses documentos para poder defender-se de eventual cobrança? O transcurso do tempo é prejudicial ao direito de defesa do executado.

Constatado esse prejuízo ao direito de defesa do executado, analisamos se a desconsideração da citação como ato necessário à interrupção da prescrição tributária era um ato adequado, necessário e proporcional à preservação dos créditos tributários, já que, caso não o fosse, a medida violaria e princípio do devido processo legal e seria, portanto, inconstitucional. 
Realizamos essa análise e concluímos que, a despeito de ser adequada, a medida em questão não passa pelo crivo da necessidade, já que há uma série de outras medidas menos gravosas ao direito de defesa, que podem ser adotadas pelas procuradorias para evitar que os créditos fiscais não sejam prescritos.

Dessa forma, concluímos que as alterações promovidas pela Lei Complementar $n^{\circ} 118 / 2005$ e pelo Recurso Especial n $n^{\circ} 1.120 .295 / S P$ violam o princípio do devido processo legal e, portanto, são inconstitucionais. Cabe, assim, aos operadores do direito demonstrar essa inconstitucionalidade, a fim de abrir os olhos do Poder Legislativo e do Poder Judiciário, a fim de que seja reestabelecida a ordem constitucional acerca da questão.

\section{REFERÊNCIAS BIBLIOGRÁFICAS}

ÁVILA, Humberto. Princípios e regras e a segurança jurídica. RDE - Revista de Direito do Estado, São Paulo, 2012, v. 21, 313-310. set. 2008 .

O que é "devido processo legal”?. Revista de Processo. São Paulo, n.163, p. 50-59,

BECHO, Renato Lopes. Execução fiscal: análise crítica. São Paulo, Noeses, 2018.

Desdobramentos das decisões sobre responsabilidade tributária de terceiros no STF: regras matrizes de responsabilização, devido processo legal e prazos de decadência e prescrição. Revista Dialética de Direito Tributário, v. 204, setembro 2012.

BRASIL, Câmara dos Deputados. Questão de Ordem 480 no Projeto de Lei Complementar $\mathrm{n}^{\mathrm{o}} 72$, de 23 de julho de 2003. Altera e acrescenta dispositivos da Lei ${ }^{\circ} 5.172$, de 25 de outubro de 1966 - Código Tributário Nacional, e dispõe sobre a interpretação do inciso I do artigo 168 da mesma Lei.

BUENO, Cassio Scarpinella. Curso sistematizado de direito processual civil: teoria geral do direto processual civil. 4 ed., Vol. 1. São Paulo: Saraiva, 2010.

Curso sistematizado de direito processual civil: direito processual público e direito processual coletivo. 4 ed., Vol. 2. São Paulo: Saraiva, 2014.

Curso sistematizado de direito processual civil: tutela jurisdicional executiva. 2 ed., Vol. 3. São Paulo: Saraiva, 2009. 
CARRAZZA, Roque Antonio. Curso de direito constitucional tributário. 30. ed. São Paulo: Malheiros, 2014. Reflexões sobre a obrigação tributária. São Paulo: Saraiva, Noeses, 2010.

CINTRA, Antonio Carlos de Araújo. GRINOVER, Ada Pellegrini. DINAMARCO, Cândido Rangel. Teoria geral do processo. 23. ed. São Paulo: Malheiros, 2007.

CONSELHO NACIONAL DE JUSTIÇA, Justiça em números 2019. Brasília: CNJ, 2019

GRINOVER, Ada Pellegrini. Os princípios constitucionais e o código de processo civil. São Paulo: Bushatsky, 1975.

MACHADO SEGUNDO, Hugo de Brito. Processo Tributário. São Paulo: Atlas, 2004

MELlo, Celso Antônio Bandeira de. Curso de direito administrativo, 26. ed. São Paulo: Malheiros, 2008.

NERY JUNIOR, Nelson. Princípios do processo na Constituição Federal. 12.ed. São Paulo: Revista dos Tribunais, 2016.

WAMBIER, Luiz Rodrigues; TALAMINI, Eduardo. Curso Avançado de Processo Civil: teoria geral do processo e processo de conhecimento, 15. ed. São Paulo: Revista dos Tribunais, 2015.

Data de Submissão: 01/05/2020

Data de Aceite: 04/08/2020 